\title{
ISLAMIZATION AND THE TRANSITION OF POWER IN NUSANTARA ACCORDING TO KIAI ABUL FADHOL'S AHLĀ AL-MUSĀMARAH
}

\author{
Moh. Ashif Fuadi \\ Universitas Islam Negeri Raden Mas Said Surakarta, Indonesia \\ E-mail: moh.ashiffuadi@iain-surakarta.ac.id
}

\begin{abstract}
The discourse on the process of Islamization in Nusantara (Indonesia) still attracts academic attention. This article discusses the history of Islamization in Nusantara as represented by the book of Ablà alMusāmarah written by Kiai Fadhol. He mentions Ten saints (Walisepulub) as propagators of Islam in Java, adding one to the nine generally known as Walisongo. He also describes that Islam was brought to Nusantara by the scholars ('ulamā') from Pasai, who carried da'wah out through several channels of Islamization. Using the library research method, this article shows no significant difference between the Walisepulub and the Walisongo characters. The Islamization of Nusantara presented in the book was intensified through the diaspora of kinship marriages, the education of the Pesantren Ampel Denta, which produced a network of students, and the establishment of Demak Kingdom, which strengthened the influence of Islam over the Javanese population.

Keywords: Kiai Fadhol; Aḅlā al-Musāmarah; Walisepulub; transition of power.
\end{abstract}

\section{Introduction}

The history of Islamization in Nusantara is a reconstruction process that explains the beginning of the coming of Islam to spread throughout Nusantara. According to Ricklefs, the vital process will still be a discourse in presenting academic studies of 
the history of Islamization from the aspect of time (when), from where (origins) and who brought and spread it. ${ }^{1}$

There are four theories about the coming of Islam to Indonesia, namely the beginning of Indian theory by Dutch orientalists Snouck Hugronje and J. Pijnapel, ${ }^{2}$ Persian theory referring to Hossein Djajadiningrat and Umar Amir Husein, ${ }^{3}$ Arab theory by Crawfurd supported by Keyzer, P.J. Veth and Muhammad Naquib al-Attas, ${ }^{4}$ and Chinese theory referring to the opinions of H.J. de Graaf and Slamet Muljana. ${ }^{5}$ In addition to these theories, it is also explained that Islam entered Nusantara through several channels of Islamization, such as trade, marriage, education, and Sufism. ${ }^{6}$

The first Islamization period in Indonesia based on some of the above theories began from the seventh century to the thirteenth century. ${ }^{7}$ According to Poesponegoro and Notosusanto, the seventh century was the beginning phase of Islam's arrival, while the thirteenth century was the phase of the spread and formation of Nusantara Muslim society. ${ }^{8}$ In later developments,

${ }_{1}$ M.C. Ricklefs, Sejarah Indonesia Modern (Yogyakarta: Gadjah Mada University Press, 1991), 3; Nor Huda, Sejarah Sosial Intelektual Islam di Indonesia (Jakarta: Raja Grafindo Persada, 2015), 1.

2 Azyumardi Azra, Islam Nusantara: Jaringan Global dan Lokal (Bandung: Mizan, 2002), 20.

${ }^{3}$ Hosein Djadjadiningrat, Islam di Indonesia, ed. Kennet Morgan (Jakarta: PT Pembangunan, 1963), 99; Miftakhul Jannah and Muhammad Nur Hadi, "Islamisasi Nusantara dan Proses Pembentukan Masyarakat Muslim," Multicultural of Islamic Education, Vol. 2, No. 1 (2018), 28.

4 Azyumardi Azra, Jaringan Ulama: Timur Tengab dan Kepulauan Nusantara Abad XVII dan XVIII: Melacak Akar-Akar Pembaruan Pemikiran Islam di Indonesia, (Jakarta: Mizan, 1994), 24; Huda, Sejarah Sosial, 5.

${ }^{5}$ H.J. de Graaf and G. Th. Pigeaud, Chinese Muslims in Java in the 15th and 16th Centuries: The Malay Annals of Semarang and Cerbon (N.p.: Monash Papers on Southeast Asia, 1984, 38.

6 Marwati Djoned Pusponegoro and Nugroho Notosusanto, Sejarah Nasional Indonesia, Vol. III (Jakarta: Balai Pustaka, 1990), 189.

7 Rosita Baiti and Abdur Razzaq, "Teori dan Proses Islamisasi di Indonesia," Jurnal Wardah, Vol. 28, No. 16 (2014), 144; Pusponegoro and Notosusanto, Sejarah Nasional, 181.

8 Ibid., 181-83. 
the spread of Islam in Nusantara affected indigenous peoples' socio-cultural and civilizational changes. ${ }^{\text {? }}$

According to Kartodirdjo, the fast spread of Islam in Nusantara had been the result of intensive preaching pioneered by the wali (saints), especially in Java. The saints have an adequate religious ability to influence the community, as well as a strong political authority of the kingdom that further strengthened their legitimacy in implementing the strategy of Islamic preaching. ${ }^{10}$

In general, the saints who spread Islam in Java are called Walisongo, who are nine in number. Although many believe that the number is more than that, the existence of Walisongo is undeniable and greatly influenced the development of Islam in Java up to the present. Some opinions categorize Walisongo into several periods and this viewpoint is of course subject to debates. However, it has been agreed that Walisongo include such figures as: Maulana Malik Ibrahim (Sunan Gresik), Raden Ali Rahmatullah (Sunan Ampel), Maulana Makdum Ibrahim (Sunan Bonang), Raden Sahid (Sunan Kalijaga), Maulana Syarif Hidayatullah (Sunan Gunung Jati), Raden Qasim (Sunan Drajad), Raden Paku/Maulana Ainul Yakin (Sunan Giri), Raden Ja'far Shodiq (Sunan Kudus), and Raden Umar Said (Sunan Muria). ${ }^{11}$

Among the Nusantara literature that presents in detail the genealogy of the founder of Demak sultanate is Tärikh al-Awliya': Tärikh Wali Sanga by Kiai Bisyri Musthofa of Rembang, the book Aḅlā al-Musāmarah fì Hikēayat al-Awliyā' al-'Ashrah by Abū al-Faḍl (Kiai Fadhol) of Tuban, and the manuscript of Shaykh Anom. In particular, the work by Abul Fadhol, Aḅlā al-Musamarah, describes the flow of Islamization from the point of view of biographical history and genealogy of the spreaders of Islam in the land of Java. The book also explains the process of da'wah carried out by spreaders of Islam, generally called Walisongo. In addition, the book implies the typology of the da'wah in the process of Islamization.

\footnotetext{
9 Syed Muhammad Naquib Al-Attas, Islam dan Sejarab Kebudayaan Melayu (Kuala Lumpur: Universiti Kebangsaan Malaysia, 1972), 19.

${ }^{10}$ Sartono Kartodirjo, Introduction to The History of New Indonesia: 1500-1900, From Emporium To Empire (Jakarta: Gramedia, 1987), 23.

11 Achmad Syafrizal, "Sejarah Islam Nusantara," Islamuna: Jurnal Studi Islam, Vol. 2, No. 2 (2015), 252.
} 
The writing of historical books by the pesantren scholars is rarely found. This fact illustrates the prevalence of dichotomy in readings between within and outside pesantren. The dimensions of explanation in Kiai Fadhol's work are quite different from the reading of history developed outside the pesantren world, and therefore it seems ahistorical, and many do not correspond to the historical reality, especially regarding the name of location as well as the character. Due to the absence of sources or references, it is difficult to confirm whether or not the information provided in the book is based on historical methodology. In fact, some figures and places were written in the book after their tombs and their place being found. The tomb (makam) is one of the authentic proofs that a person ever lived, especially for Muslims. Everything can be used for toponym analysis or be tracked with names, such as Raden Kusen who has another name Pangeran Terung, where Terung is one of the areas in Sidoarjo, East Java.

The explanation by Kiai Fadhol are very different from the explanation of the coming of Islam to Indonesia, which is studied in formal education. Despite many theories regarding the spread of Islam in Java, Kiai Fadhol made his version in his book Aḅla alMusamarah. Uniquely, the scholars of the archipelago, in general, are more interested in producing works on fiqh, Arabic language (nahpw) or abridged works (mukhtasar) of the great books such as Tafsìr Ibn Kathìr, Ibya' 'Ulüm al-Din, and others. However, Kiai Fadhol decided to write works on Islamic history. The history of Islam in Java is written using complicated methodologies and theories, such as Atlas Walisongo by Agus Sunyoto, Jaringan Ulama Timur Tengah dan Kepulauan Nusantara by Azra, Runtubnya Kerajaan Hindu-Jawa dan Timbulnya Negara-negara Islam di Nusantara by Muljana, Menemukan Peradaban: Jejak Arkeologis dan Historis Islam Indonesia by Ambari, and others. As the pesantren scholar, Kiai Fadhol wrote the history of Islam in Indonesia as a work of prose that flows and meets the intrinsic elements.

The book Aḅla al-Musamarah is among the works on Islamic history in the archipelago written in Arabic, while in general the history of Islamization is written in Indonesian (Malay) or foreign languages such as English or Duthch, if the author is a foreigner. In writing his work, Kiai Fadhol did not mention the sources. It is actually not a problem because there are also historians who never 
include footnotes or references in his writings, such as Hamka. However, this is slightly different from historical works by modern historians who pay a great attention to sources.

Kiai Fadhol explains genealogy (nasab) in detail, but the mention of unknown names can confuse readers. In the title of the book, Kiai Fadhol used the word "ashrah," which means ten as the number of saints as spreaders of Islam in Java. In fact, what has been popular in Javanese society is Walisongo, not Walisepuluh. Therefore, the discussion on the Islamization of the archipelago in the view of pesantren scholar is quite interesting. It is also interesting to answer the figure of $W$ alisepuluh in Aḅla al-Musämarah and the difference from Walisongo.

Interestingly, the book contains the term $W$ alisepuluh, which plays an important role in spreading Islam in Java and has a good relationship with the kingdom in Java. The discussion will include the process of Islamization in Nusantara by the preaching of the saints (wali). Starting from the genealogy of spreaders of Islam in Java who still have kinship relationship, the explanation then includes Ampel Denta as the center of Islamic education and da'wah led by Sunan Ampel in that one of his students Raden Patah became the leader in the first Islamic kingdom in Java. Islamic da'wah had expanded until the collapse of Majapahit kingdom due to Demak attack which at the same time signified the beginning of Islamic glory in Java. In this regard, the typology of dawah by the saints will be explored to reveal the characteristics of da'wah which was easily accepted by Javanese people.

This article will focus on two questions regarding the channels of Islamization and the process of transition of power from Majapahit to Demak, as explained by Abul Fadhol in his Aḅla alMusamarah. The purpose of this article is to analyze the pattern of the movement of $d a^{\prime} w a h$ of the saints, especially in the land of Java, and to analyze the process of transition from Majapahit of HinduBuddha to the Islamic kingdom.

Previous researches related to the spread of Islam in the Nusantara is quite a lot. Baiti and Razzaq's research focuses on the theory and process of Islamization in Indonesia, ${ }^{12}$ while Achmad Syafrizal deals with the history of Islam Nusantara. ${ }^{13}$ In addition,

\footnotetext{
12 Baiti and Razzaq, "Teori dan Proses."

${ }^{13}$ Syafrizal, "Sejarah Islam."
} 
Jannah and Hadi study the Islamization of the Nusantara and the formation of Muslim communities, ${ }^{14}$ Amin and Ananda focus on the arrival and spread of Islam in Southeast Asia. ${ }^{15}$ There is also research on Demak Kingdom related to the role of Raden Patah in developing the kingdom in 1478-1518. ${ }^{16}$ However, none of the previous researches employ the sources such as Aḅla al-Musämarah by Kiai Fadhol to research the history of Islam in Nusantara and the transition from Majapahit to Demak.

The method used in this study is library research. References or sources in library research can be done by analyzing articles, books, and written sources relevant to the theme. ${ }^{17}$ Then to get accurate analysis results can be done by interpretation analysis to uncover the purpose and answers to the research problems raised. ${ }^{18}$

\section{Kiai Fadhol: Biography and Works}

Kiai Fadhol was born in Sedan, Rembang, Central Java, in 1921. He is the son of Kiai Abdul Syakur through his second wife (Nyai Sumiah). He has a brother called Kiai Abul Khair. As from his first wife, Nyai Mashfufah binti Abdul Hadi Sedan, Kiai Abdul Syakur has six children, namely Fadhil, Fadhol, Nafisah, Nafi'ah, Munirah, and Said. From his father, the genealogy (nasab) of Kiai Fadhol continued with Kiai Saman, Diponegoro's army during the Java War (1825-1830). ${ }^{19}$ Kiai Fadhol only studied to his father, Kiai Abdul Syakur, and Kiai Hasyim Asy'ari at Pesantren Tebuireng. Although he never received education in the Middle East (Haramain), his knowledge is recognized by kiais of Nusantara,

\footnotetext{
14 Jannah and Hadi, "Islamisasi Nusantara."

${ }^{15}$ Faizal Amin and Rifki Abror Ananda, "Kedatangan dan Penyebaran Islam di Asia Tenggara: Telaah Teoritik tentang Proses Islamisasi Nusantara," Analisis: Jurnal Studi Keislaman, Vol. 18, No. 2 (2018).

16 Ana Ngationo, "Peranan Raden Patah dalam Mengembangkan Kerajaan Demak pada Tahun 1478-1518," Kalpataru: Jurnal Sejarah dan Pembelajaran Sejarah, Vol. 4, No. 1 (2018), 28.

17 James Danandjaja, Folklor Indonesia: Ilmu Gosip, Dongeng, dan Lain-lain (Jakarta: PT. Pustaka Utama Grafiti, 1997), 87.

18 Amin and Ananda, "Kedatangan dan Penyebaran," 71.

19 Amirul Ulum, 3 Ulama Kharismatik Nusantara (Yogyakarta: Global Press, 2016), 5. Najihah Kamilatul Ula, "KH Abul Fadhol (1917 M-1989 M): Kiai Kharismatik dari Pondok Pesantren Darul Ulum Senori Tuban" (BA. Thesis-UIN Sunan Ampel Surabaya, 2020), 19.
} 
one of them being Abuya Dimyathi Pandeglang Banten. He felt sorry because he had never studied with Kiai Fadhol. ${ }^{20}$

Kiai Abdul Syakur was a student of Shaykh Kafrawi Tuban who then continued his education along with his college brother, Kiai Umar bin Harun who became the son-in-law of Kiai Ghozali bin Lanah, in Haramain. Kiai Abdul Syakur was a teacher to Shaykh Nawawi Banten, Shaykh Abu Bakar Syatha, Shaykh Zaini Dahlan, Shaykh Madah, Shaykh Mukri, Shaykh Zawawi, and many Haramain scholars whose knowledge is well recognized. In addition, Kiai Abdul Syakur has also been a teacher to Kiai Sholeh Darat Semarang. ${ }^{21}$

As a child, Kiai Fadhol was famous for being rebellious or delinquent (Javanese: mbeling). His delinquency is not only in the pesantren but also in his home. He often played at the Dutch headquarters without any fear and hung out with the people there. From this habit, he can master Dutch very well. ${ }^{22}$ Kiai Fadhol was married to Kiai Jadid Tuban's daughter. After marriage, he was asked to move to Senori, Tuban, to teach in pesantren and madrasah. Despite the homeliness of his pesantren, there studied many students who later became influential figures such as Kiai Abdullah Faqih of Langitan, Kiai Maimoen Zubair of Sarang, Kiai Hasyim Muzadi, Kiai Dimyati Rois, and others. ${ }^{23}$

Kiai Fadhol is a prolific scholar of Nusantara as evidenced by his works writen in Arabic such as al-Jawharat al-Saniyyah fi ' $\mathrm{Ilm}$ alSarf, Käfiyat al-Ṭlläb fì 'Tlm al-Naḥw, al-Durrat al-Saniyyah fi $\mathrm{Tlm}$ alNaḥw, Sullam al-Tulläb fì 'Tlm al-Naḥw, Zubad al-I'räb fi Tlm al-Naḅw, İdāḥ al-Masälike Ilā Alfiyyat Ibn Mälik, Tashil al-Masälik Sharḥ Alfiyyat Ibn Mälik, Tarjamat Alfiyyat Ibn Mälik, al-Durr al-Farid fì Sharb alJawharat al-Tawhìd, Kifäyat al-Tulläb fì al-Qawāid al-Fiqhiyyah, alWardat al-Babiyyah fi Bayān al-Istilähät al-Fiqhiyyah, al-Kawäkib al-

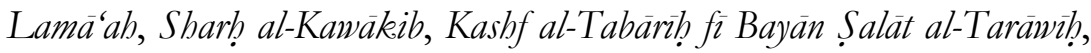
al-Kawākeib al-Säti' Sharḥ 'Alā Jam' al-Jawāmi', Aḅlā al-Musāmarah fi Hikeāyät al-Awliyā' al-'Ashrah, Sharh al-Manzumah (Babjat al-Hāmr) li

20 Asnawi, Syech Abul Fadol As-Senori at-Tubani (Tuban: Pesantren Langitan, 2004), 8.

21 Zubair, Taräjim Mashāyikh al-Ma'ähid al-Diniyah bi Sarang al-Qudam $\vec{a}$ (Rembang: Maktabah al-Anwar, n.d.), 43.

22 Asnawi, Syekh Abul Fadol, 9; Ula, "KH Abul Fadhol," 21.

${ }^{23}$ Ulum, 3 Ulama Kharismatik, 15. 
Umar al-Wardi, Sharh Matn al-Jurumiyah, al-Manzumah fi $\mathrm{Tlm}$ alTasawnuf, al-Manzar al-Muwāji fì $\mathrm{Tlm}$ al-'Arüd wa al-Qowäfi, Khutbat al-Jum'ah, Bahjat al-Hāwī, Naz̧m wa Tarjamat Qasidat al-Burdah, and Pengreksogomo. ${ }^{24}$

Picture 1. Books by Kiai Abul Fadhol Senori Tuban ${ }^{25}$

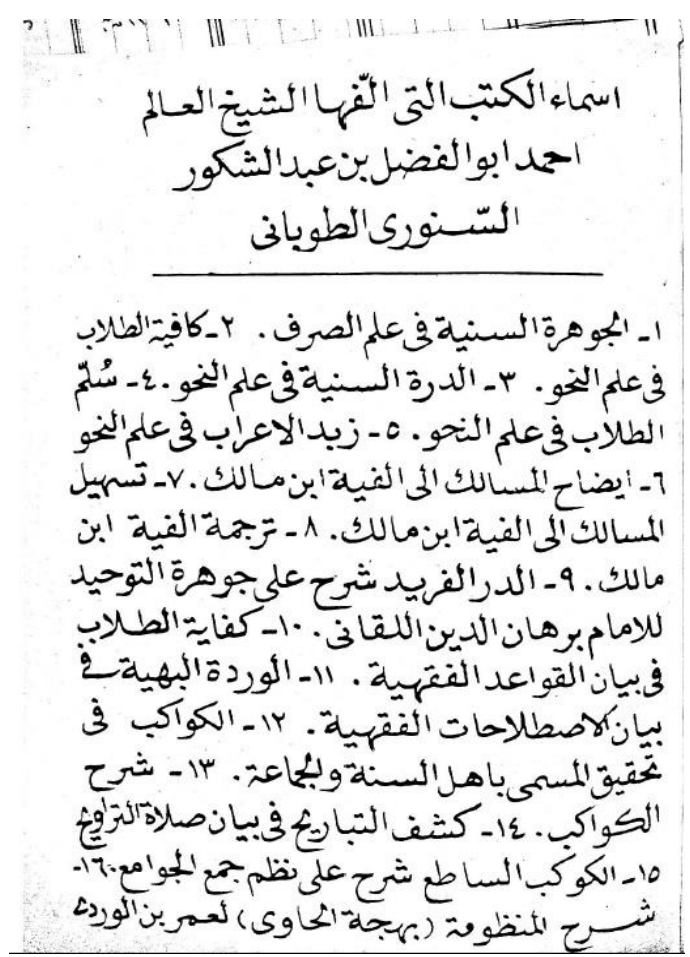

The book al-Kawäkib al-Lamä'ah was written and completed by Kiai Fadhol on 11 Jumādā al-Thānī $1381 \mathrm{H}^{26}$ In the book, Kiai Fadhol explains the creed of Ahlusunnah wal Jamā'ah, following the tradition of Shaykh Abā Hasan al-Ash'ārē and Shaykh Abū

\footnotetext{
${ }^{24}$ Ibid., 20.

25 Abul Fadhol, Käfizat al-Tullāb fì Tlm al-Naḥw (Tuban: Majelis Ta'lif wal Khattath, n.d.).

${ }^{26}$ Ibid., 21; Abul Fadhol, Sharḅ al-Kawäkib al-Lamä'ah fì Tahquiq al-Musammā bi Abl Sunnah wa al-Jamā'ab (Tuban: Majelis Ta'lif wal Khattath, n.d.), 2.
} 
Manșūr al-Māturīdī. ${ }^{27}$ The book on tawhìd entitled al-Durr al-Farìd fì Sharb al-Jawharat al-Tawhid was completed on Friday the $13^{\text {th }}$ of Dhū al-Qa'dah $1386 \mathrm{H}$. The book amounts to 663 pages. In his preface, Kiai Fadhol explains that as a child he had memorized the book Jawharat al-Tawhid by Burhanuddin Ibrahim al-Lagani. ${ }^{28}$ One of its contents is to follow one of the four madhhabs, namely Hanafí, Mālikī, Shāfi'î, and Hanbalī, in practising law in the books of madhhab following the teachings of Ahlussunnah wal Jama'ah. ${ }^{29}$

As for the book Kashf al-Tabärịh fi Salät al-Taräwīh was written by Kiai Fadhol because of the differences among Muslims about the number of raka'at in the Taraini hrayer, especially the evidence that supports 20 raka'ats. At the same time, the book Kifayyat alTulläb fi al-Qawāid al-Fiqhiyyah was written Kiai Fadhol in the form of nazm or shir (verse) that consists of 115 verses extracted from the book al-Ashbāh wa al-Nažäir by al-Suyūtị. This treatise was completed on Sunday $17^{\text {th }}$ of Muharram $1394 \mathrm{H}$, and published by Maktabah Salim bin Nabhan Surabaya. Kiai Fadhol died in $1991 .^{30}$

\section{Aḥlā al-Musāmarah fi Hikāyat al-Awliyā' al-‘Ashrah}

Aḅla al-Musamarah explores the journey of the spreaders of Islam. In the book's introduction, Kiai Fadhol explains the importance of knowing the history of the ancients, which is enshrined into the Qur'ān to be an example for the next generation. This book was completed on $5^{\text {th }}$ of Muharram $1381 \mathrm{H}$, or June 19, 1961. The publisher of this treatise is Majelis Ta'lif wal Khattat in Bangilan Tuban. ${ }^{31}$

In general, the book explains the history of Islam in Java up to the establishment of Demak Kingdom. The book describes that the ancestors of the Javanese used to adhere to animism and dynamism, as well as to Hinduism and Buddhism. From history, we get information about Majapahit Kingdom with Hindu-

\footnotetext{
27 Ibid., 28-32; Wasid, "Nalar Moderatisme Islam dalam Kitab Sharah alKawakib al-Lama'ah by Kiai Abul Fadhal Senori Tuban," 2nd Proceedings Annual Conference for Muslim Scholars, No. 1 (April 2018), 209.

28 Ulum, 3 Ulama Kharismatik, 26.

${ }^{29}$ Maimoen Zubair, Fuyūdhat al-Rabbānìyah (Rembang: Maktabah al-Anwar, n.d.), 9.

30 Wasid, "Nalar Moderatisme," 209.

31 Ulum, 3 Ulama Kharismatik, 29.
} 
Buddhist pattern in Trowulan as its center of government with its last king Prabu Brawijaya V. It is inconceivable that the king will later be defeated by his son who was then crowned as the king by the saints with Demak Bintara as its center of government.

The first part of the book describes the kinship relationship of the saints who opened new land (babat alas) with their wealth and lives in pioneering Islamic da'wah in Java, with a success marked by the establishment of Islamic government in Demak under Raden Patah, son of Prabu Brawijaya V. The second part narrates the war between Muslim soldiers of Demak Bintara and Majapahit troops. An exciting event in the battle was the appointment of Demak warlord Raden Usman Haji (Sunan Ngudhung), the father of Sunan Kudus, by Raden Rahmat's student Prabu Brawijaya to be a duke in Terung, namely Raden Kusen.

\section{Review of Aḥlā al-Musāmarah: Islamization Through Marri- age, Education, and Sufism}

Since its coming and development, Islam has entered the Nusantara through several channels of Islamization, such as trade, marriage, education, and Sufism. ${ }^{32}$ Concerning the marriage channel, the book explains a genealogical approach that Sayyid Ibrahim Asmorokondi is a descendant of the Prophet with genealogy as follows: Sheikh Ibrahim Asmorokondi b. Shaykh Jumadil Kubra b. Mahmud Kubra b. Zainul Husen b. Zainul Kubro b. Zainul Adzim b. Ali Zainal Abidin b. Husen b. Fatimah daughters of Muhammad. Jumadil Kubra has three children: Shaykh Maulana Ishak, Shaykh Ibrahim Asmorokondi, and Sayyidah Asfa, the wife of the son of Roman King Abdul Majid..$^{33}$

Shaykh Ibrahim reached adulthood when he travelled to the land of Champa and managed to drown his king so that he positioned Shaykh Ibrahim as a close man. Shaykh Ibrahim was also taken by King Champa son-in-law. He married with one of children of the king, Dewi Condrowulan. The marriage between Shaykh Ibrahim and Condrowulan had three children: Raden Raja Pandhito, Sunan Ampel, and Sayyidah Zainab. ${ }^{34}$

\footnotetext{
32 Pusponegoro and Notosusanto, Sejarah Nasional, 189.

33 Abul Fadhol, Aḅlā al-Musāmarah fì Hikeāyat al-Awliyā' al-'Ashrah (Tuban: Majelis Ta'lif wal Khattath, 1994), 3.

${ }^{34}$ Ibid., 3.
} 
It is mentioned that in early $1440 \mathrm{CE}$, there had come two brothers from Champa, namely Ali Murtadlo with Ali Rahmatullah with Abu Hurairah, who became his second cousin. For the services of his aunt, who was married to the Majapahit King Sri Prabu Kertawijaya who ruled at the time (1447-1451), Ali Murtadlo was appointed king of Pandhito in Gresik, while his brother Ali Rahmatullah was appointed as Imäm and religious leader in Ampel Denta Surabaya. Starting from the Champa network, Islam can finally develop through children, sons-in-law, relatives, and students through the Walisongo da'wah network, which is thought to be formed around $1479 .{ }^{35}$ Based on the presentation of Kiai Fadhol, Raden Raja Pandhito is Ali Murtadlo, brother of Ali Rahmatullah (Sunan Ampel).

In Aḅlā al-Musämarah, Kiai Fadhol mentions that Sunan Ampel had seven children; five children of the first wife, Raden Ayu Condrowati b. Arya Teja, and two children from his second wife, Mas Karimah b. Kiai Kembang Kuning. ${ }^{36}$ In line with Kiai Fadhol's explanation, in another source, it is mentioned that Sunan Ampel is married to Raden Ayu Condrowati, who holds the title Nyai Ageng Manila (daughter of Arya Teja) and has children, Raden Makdum Ibrahim (Sunan Bonang), Raden Qasim (Sunan Drajat), Nyai Pangulu, Nyai Ageng Manyuran, and Nyai Ageng Maloka. ${ }^{37}$

The method of da'wah through marriage continues to be carried out by Sunan Ampel both to his children and students. Through Nyai Murtosiyah, the daughter of Kiai Kembang Kuning was married to Sunan Ampel's student Raden Paku (Sunan Giri). Nyai Murtosiyah's younger sister, Nyai Murtosimah, was married to Raden Patah. Another student of Sunan Ampel, Raden Kusen, Raden Patah's brother, was married to his grandson, Nyai Wilis. ${ }^{38}$

\footnotetext{
35 Agus Sunyoto, Atlas Wali Songo (Jakarta: Pustaka IIman \& LT NU, 2012), vi; Yuyus Suheman, Sejarah Perintisan Penyebaran Islam di Tatar Sunda (Bandung: Pustaka, n.d.), 45.

${ }^{36}$ Fadhol, Aḅlà al-Musāmarah, 31.

${ }^{37}$ Sunyoto, Atlas, 123.

${ }^{38}$ Ibid., 199.
} 
Some of the students who studied under Sunan Ampel include Shaykh Siti Jenar (Sayyid Abdul Jalil), Sayyid Amir Husain, Sunan Kudus, Sunan Muria, Raden Patah, and Amir Hamzah. These men went to Ampel to serve Sunan Ampel and learned from him. Raden Qasim (Sunan Drajat) became their leader in learning. Another student was Raden Paku (Sunan Giri), who is narrated to be thrown into the sea by Maulana Ishak over the Blambangan riots and found by traders from Gresik who were sailing, then they handed the baby to Nyai Gedhe Pinatih to be adopted. At the same time, Shaykh Siti Jenar is the son of Sayyid Abdul Qadir b. Maulana Ishak of Pasai's wife. ${ }^{39}$

After serving Sunan Ampel, Raden Patah, for instance, was married to Sunan Ampel's daughter, named Nyai Murtasimah. He was told to go westwards until he found a fragrant bamboo in the forest called Bintara. Bamboo trees in the forest, one by one he touched (Javanese: demak-demek) to find one which smelled good. Therefore, the area is named "Demak," from the Javanese word demak-demek, 'touch one by one.' Raden Patah built a house and settled there with spiritual exercises to God and then well-known as Sunan Demak. He continued to preach Islam until Demak Bintara became a large area. ${ }^{40}$

In his book, Sunyoto mentioned that Sunan Ampel ordered Raden Patah to open new land to Glagah Wangi village, but because of many disturbances from the rulers in the village, Raden Patah and his followers moved to Demak and established a town there. He succeeded in raising Demak to become a large kingdom. As previously mentioned, Raden Patah, as a Majapahit breed, tried to establish good relations with Majapahit by routinely facing Prabu Brawijaya and declared loyalty until Demak's forces carried out an attack on Majapahit. ${ }^{41}$

One of the media for Islamization is Sufism. Based on its tendencies and characteristics, sufism can be divided into three madhhabs, namely Falsafi sufism, Salafi sufism, and Sunni sufism (Akhlaqi/Amali) although with different manifestations. In

\footnotetext{
${ }^{39}$ Fadhol, Aḅlā al-Musāmarah, 37.

${ }^{40}$ Ibid., 41. Further explanation on the origin of the name "Demak," see Imron Abu Amar, Sejarab Ringkas Kerajaan Islam Demak (Kudus: Menara Kudus, 1996), 19.

${ }^{41}$ Sunyoto, Atlas, 383.
} 
general, the practitioners of sufism can be said to agree that the teachings of sufism are tarkiyat al-nafs (purification of self, purification of body, speech, thought, heart, and soul), through takhalli, tahalli, and tajalli to achieve closeness or union with God Almighty. ${ }^{42}$

The analysis of sufism shows the efforts of sufis with various traditions that they adhere to have a conception of the way (tariqab) to God. This path begins with spiritual exercises (riya dab), then gradually goes through various phases, known as maqäm (level) and states (circumstances), and ends with knowing (ma'rifah) God. The story of recognition (ma'rifah) became a common goal pursued by sufis. Sufi attitudes and behavior frameworks are manifested through specific practices and tarekat methods. ${ }^{43}$

According to Kiai Fadhol, Sunan Giri studied with Sunan Ampel. He followed Sunan Ampel as a practitioner of the Tarekat Naqshbandiyah. ${ }^{44}$ There are various opinions about the tarekat embraced by Sunan Ampel and Sunan Giri. Kiai Fadhol mentions thems as practitioners of the Tarekat Naqshbandiyah, while according to the genealogical sources of Gresik regent, Kiai Tumenggung Poesponegoro, both are practitioners of the Tarekat Shattariyah. ${ }^{45}$

Meanwhile, Shaykh Siti Jenar is not married. He studied with Sunan Ampel and pursued sufism, and studied the science of ma'rifah. He ascended to the level of mukashafah (the opening of the inner), and drowned in waḅdat al-wujüd (the fusion of servants with God) and mortality (feel vanished) entirely from other than Allah. He had an abundance of quds (holiness) whose inner nature could not accommodate him, as the abundance of the ilahiyah should be hidden, but he leaked it so that an oral statement appeared: Ana alHaq (I am God). This resulted in his blood being "permitted" by Sunan Bonang until he was executed. ${ }^{46}$

\footnotetext{
42 Aly Mashar, "Tasawuf: Sejarah, Madzhab, dan Inti Ajarannya," Al-A'raf: Jurnal Pemikiran Islam dan Filsafat, Vol. 12, No. 1 (2015), 94.

43 Abū al-Wafā al-Ghanīmī al-Taftāzānī, Madkhal ilā al-Tașawwuf al-Islāmì (Bandung: Pustaka, 1985), 35.

${ }^{44}$ Fadhol, Aḅlà al-Musāmarah, 38.

45 Sunyoto, Atlas, 218.

${ }^{46}$ Fadhol, Aḅlà al-Musāmarah, 46.
} 
Sunyoto mentioned that Shaykh Siti Jenar is the son of Datuk Shaleh, a cleric from Malacca. He became a controversial member of Walisongo but not on a theological level (tawhid) about waḥdat al-wujūd, but rather anti-feudalistic attitudes. He considered social caste in Demak Kingdom body between kawula (people) and gusti (king), which caused social strata gaps. With this social renewal, more public sympathy is gained, so that the influence of Shaykh Siti Jenar is expanding. The concept of an egalitarian society gives space to open a new land called Lemah Abang. The existence of community in Lemah Abang villages refers to the establishment of Lemah Abang, which gave rise to abangan variants. ${ }^{47}$ According to Kiai Fadhol, Shaykh Siti Jenar was unwilling to help Demak to fight against Majapahit.

Shaykh Siti Jenar then received the death penalty from Walisongo or the ruler of Demak because of his controversial teaching: Manunggaling Kawula-Gusti (servant-Creator union). What experienced by Shaykh Siti Jenas is similar to that experienced by the sufi al-Hallāj (d. 922) in the history of Islam, who developed a controversial concept of bulul: a condition that is believed that God enters into the physical being, occupies it, and merges with the creature, so it can be said that he is God because the element of lähüt (deity) has dominated the nasüt (humanity) element that exists in the creature. Thus, it is not surprising that Kiai Fadhol mentioned al-Hallāj's name in discussing Shaykh Siti Jenar. ${ }^{48}$

\section{Discussion of Walisepuluh in Ahlā al-Musāmarah}

The Walisepulub (ten guardians), according to Kiai Fadhol, were: Amir Haji (Sunan Kudus), Haji Usman (Sunan Manyuran), Raden Syahid (Sunan Kalijaga), Raden Prabu (Raden Paku's son), Sayyid Muhsin (son-in-law of Sunan Ampel), Raden Qasim (Sunan Drajat), Raden Said (Sunan Muria), Raden Paku (Sunan Giri), Raden Patah, and Raden Makdum Ibrahim (Sunan Bonang). ${ }^{49}$

\footnotetext{
47 Sunyoto, Atlas, 314.

${ }^{48}$ Editorial Team, Ensiklopedi Tasawuf, Vol. 1 (Bandung: Angkasa, 2008), 438-40.

49 Fadhol, Aḅlā al-Musāmarah, 71-77. Sayyid Muhsin, known as Sunan Wilis, is the husband of Sayyidah Muthma'inah, Sunan Ampel's daughter. Meanwhile, three Dukes: Adipati Pakis, Adipati Luwono, Adipati Ponorogo Batoro Katong who used to help Majapahit converted to Islam and promised to help Demak Kingdom.
} 
Picture 2. $W$ alisepuluh in the Book of Kiai Abul Fadhol ${ }^{50}$

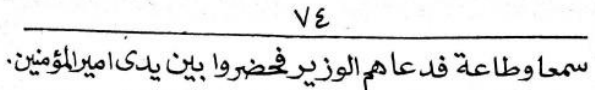

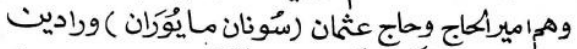

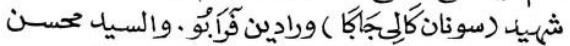

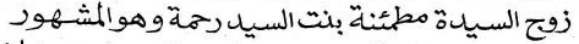

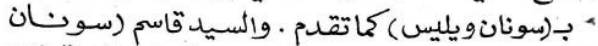

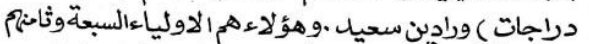

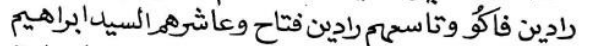

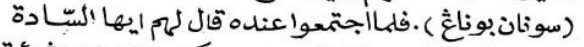

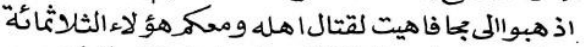

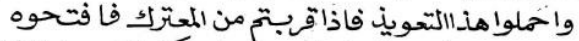

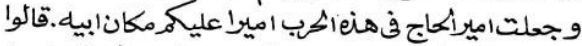

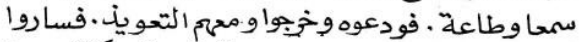

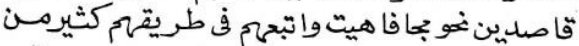

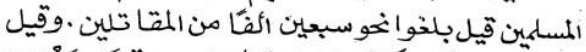

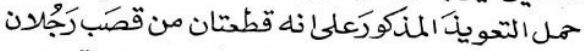

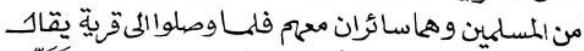

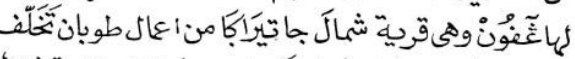

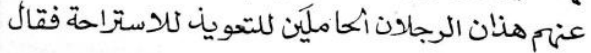

Regarding the existence of $W$ alisepuluh, there is information about the spread of Islam in the archipelago of the early period by Sultan Muhammad I of the Ottoman. According to Kanz al-Ulum by Ibn Battuta, the first period of Islam is an Ottoman envoy who had a mission to spread Islam through Gujarat (India) to Java. Early spreaders of Islam include: Maulana Malik Ibrahim (Sunan Gresik), Maulana Ishak (Pasai), Shaykh Jumadil Kubro (Trowulan Mojokerto), Maulana Al Maghribi (Jatinom Klaten and Cirebon), Maulana Malik Israil (Cilegon), Maulana Muhammad Ali Akbar (Cilegon), Maulana Hasanuddin (Banten), Maulana Aliyuddin (Banten), and Shaykh Subakir (Magelang)..$^{51}$

According to Mas'ud, before Sunan Ampel, the process of Islamic da'wah was initiated by Maulana Malik Ibrahim (d. 1419) who then received the title "spiritual father." This was caused by

\footnotetext{
${ }^{50}$ Documentation of the printed book of Majelis Ta'lif wal Khattath, 2021.

${ }^{51}$ Luqman Nurhisam and Mualimul Huda, "Islam Nusantara: A Middle Way?," QIJIS: Qudus International Journal of Islamic Studies, Vol. 4, No. 2 (2016), 156.
} 
the efforts of Maulana Malik Ibrahim in researching the development of Islamic education and was seen as the "teacher" of pesantren in the early days. ${ }^{52}$ The dawah was continued by Sunan Ampel, who managed to gather members of the nine known as Walisongo, which Kiai Fadhol called Walisepuluh.

Table 1. The Comparison of Walisongo and Walisepuluh

\begin{tabular}{|c|c|c|c|c|}
\hline No. & $\begin{array}{l}\text { Walisongo } \\
\text { first period }\end{array}$ & Walisongo & Walisepuluh & $\begin{array}{l}\text { Atlas } \\
\text { Walisongo } \\
\text { version }\end{array}$ \\
\hline 1. & $\begin{array}{l}\text { Maulana } \\
\text { Malik } \\
\text { Ibrahim }\end{array}$ & $\begin{array}{l}\text { Maulana Malik } \\
\text { Ibrahim }\end{array}$ & $\begin{array}{l}\text { Haji Usman } \\
\text { (Sunan } \\
\text { Manyuran) }\end{array}$ & $\begin{array}{l}\text { Sunan } \\
\text { Ampel }\end{array}$ \\
\hline 2. & $\begin{array}{l}\text { Maulana } \\
\text { Ishak }\end{array}$ & $\begin{array}{l}\text { Sayyid Ali } \\
\text { Rahmatullah } \\
\text { (Sunan Ampel) }\end{array}$ & $\begin{array}{l}\text { Sayyid Muhsin } \\
\text { (Sunan Wilis) }\end{array}$ & $\begin{array}{l}\text { Shaykh Siti } \\
\text { Jenar }\end{array}$ \\
\hline 3. & $\begin{array}{l}\text { Shaykh } \\
\text { Jumadil } \\
\text { Kubro }\end{array}$ & $\begin{array}{l}\text { Maulana } \\
\text { Makdum } \\
\text { Ibrahim (Sunan } \\
\text { Bonang) }\end{array}$ & Sunan Bonang & $\begin{array}{l}\text { Sunan } \\
\text { Bonang }\end{array}$ \\
\hline 4. & $\begin{array}{l}\text { Maulana Al } \\
\text { Maghribi }\end{array}$ & $\begin{array}{l}\text { Raden Qasim } \\
\text { (Sunan Drajad) }\end{array}$ & Sunan Drajad & $\begin{array}{l}\text { Sunan } \\
\text { Drajad }\end{array}$ \\
\hline 5. & $\begin{array}{l}\text { Maulana } \\
\text { Malik Israil }\end{array}$ & $\begin{array}{l}\text { Maulana Ainul } \\
\text { Yakin (Sunan } \\
\text { Giri) }\end{array}$ & Sunan Giri & Sunan Giri \\
\hline 6. & $\begin{array}{l}\text { Maulana Ali } \\
\text { Akbar }\end{array}$ & $\begin{array}{l}\text { Ja'far Shadiq } \\
\text { (Sunan Kudus) }\end{array}$ & Sunan Kudus & $\begin{array}{l}\text { Sunan } \\
\text { Kudus }\end{array}$ \\
\hline 7. & $\begin{array}{l}\text { Maulana } \\
\text { Hasanuddin }\end{array}$ & $\begin{array}{l}\text { Raden Syahid } \\
\text { (Sunan } \\
\text { Kalijaga) }\end{array}$ & Sunan Kalijaga & $\begin{array}{l}\text { Sunan } \\
\text { Kalijaga }\end{array}$ \\
\hline 8. & $\begin{array}{l}\text { Maulana } \\
\text { Aliyuddin }\end{array}$ & $\begin{array}{l}\text { Raden Said } \\
\text { (Sunan Muria) }\end{array}$ & Sunan Muria & Sunan Muria \\
\hline 9. & $\begin{array}{l}\text { Shaykh } \\
\text { Subakir }\end{array}$ & $\begin{array}{l}\text { Syarif } \\
\text { Hidayatullah } \\
\text { (Sunan Gunung } \\
\text { Jati) }\end{array}$ & Raden Prabu & $\begin{array}{l}\text { Sunan } \\
\text { Gunung Jati }\end{array}$ \\
\hline 10. & - & - & $\begin{array}{l}\text { Pangeran } \\
\text { Jinbun (Raden } \\
\text { Patah) }\end{array}$ & Raden Patah \\
\hline
\end{tabular}

52 Abdurrahman Mas'ud, "Tārìkh al-Ma‘had al-Turāthī wa Thaqāfatuh," Studia Islamika, Vol. 7, No. 1 (2000), 119. 
Looking at the table above, it can be understood that the spreaders of Islam initiated the stage of Islamization in the early period before continued by Walisongo. In the view of Kiai Fadhol, Walisepuluh has a lot in common with Walisongo figures, with adding new names such as Sayyid Muhsin (Sunan Wilis), Haji Usman (Sunan Manyuran), Raden Prabu Giri, and Raden Patah so that the number is ten. This has something in common with the Sunyoto's Atlas Walisongo which mentions ten spreaders of Islam; Sunan Gresik, Sunan Ampel, Sunan Giri, Sunan Bonang, Sunan Drajad, Sunan Kudus, Sunan Kalijaga, Sunan Muria, Sunan Gunung Jati, and Raden Patah. However, Sunyoto does not term Walisepuluh as Kiai Fadhol did.

In Aḅlā al-Musamarah, Kiai Fadhol never mentions Maulana Malik Ibrahim (Sunan Gresik), but only Sayyid Ali Rahmatullah (Sunan Ampel) who lives at the same time as Sunan Gresik. Related to Sunan Manyuran (Haji Usman), Kiai Bisri Musthofa in his book Tarikh al-Awliyā' explained that he was the son of King Pandita who preached around Mandalika, Jepara. ${ }^{53}$

Meanwhile, Sayyid Muhsin, according to Kiai Bisri in Tärkikh alAwliya $\overline{\text {, }}$, he married Sunan Ampel's daughter named Siti Mutmainnah. He was titled Sunan Wilis in the Cirebon area. ${ }^{54} \mathrm{In}$ Kiai Fadhol's version, it is explained that after marrying Sunan Ampel's daughter, Sayyid Muhsin subsequently lived in the village of Wilis and was known as Sunan Wilis. ${ }^{55}$ Another member of Walisepulub is Raden Patah, who is the son of the Majapahit king from a beautiful mother named Siu Ban Ci, the daughter of the King of China. ${ }^{56}$ Raden Prabu is the son of Sunan Giri and is known as Sunan Giri II. According to Sunyoto, Sunan Giri's son is known as Sunan Giri II (Prince Zainal Abidin/Sunan Dalem). In Suma Oriental, Pires, a Portuguese traveler who came to Java in 1513-1514, described Prince Zainal Abidin's power in the agricultural areas inland. The prince is regarded by Pires as the oldest Muslim ruler in the coastal cities of Central and East Java,

\footnotetext{
53 Bisri Musthofa, Sejarah Para Wali (Tärikeh al-Awliyā) (Yogyakarta: Kalam, 2018), 16.

${ }^{54}$ Ibid., 19.

55 Abul Fadhol, Wali Tanah Jawa (Aḥlā al-Musāmarah fì Hikeàyat al-Awliyāà al'Ashrah), ed. Nous Team (Kediri: Nous Team Pustaka, 2020), 75.

${ }^{56}$ Fadhol, Aḷlā al-Musāmarah, 6.
} 
who are good friends of Pate Rodim Tua (Raden Patah) and Pate Rodim Muda (Sultan Trenggana), ruler of Demak, because of his excellent service in the development of Islam. ${ }^{57}$

In general, people know Walisongo only nine people as mentioned above. However, if traced further, the existence of Walisongo will be found the number of more than nine figures. According to Saksono, at least twenty-one walis are generally included in the circle of spreaders of Islam in the archipelago. They are Raden Rahmat (Sunan Ampel) Surabaya, Raden Paku/Prabu Satmata titled Sunan Giri in Gresik, Sunan Gunung Jati Cirebon, Maulana Makdum Ibrahim or Sunan Bonang Tuban, Sunan Drajat Lamongan, Sunan Majagung, Shaykh Ja'far Shodiq Sunan Kudus, Raden Sahid Sunan Kalijaga Kadilangu Demak, Sunan Muria Kudus, Shaykh Siti Jenar or Sheikh Lemah Abang, Sunan Ngudung Trowulan Mojokerto, Sunan Gresik or Maulana Malik Ibrahim, Sunan Wilis Cirebon, Raden Haji Usman or Sunan Manyuran Mandalika, Khalifah Husein or Sunan Kertosono, Ki Ageng Pandanarang or Sunan Tembayat Klaten, Ki Cakrajaya or Sunan Geseng Lowanu Purworejo, Sunan Giri Prapen, and Sunan Padusan. ${ }^{58}$

\section{Kiai Fadhol's View on the Transition of Power from Majapahit to Demak}

History records Majapahit, from the thirteenth to fifteenth centuries, as one of the largest kingdoms in Nusantara founded by Raden Wijaya in 1293. The event was commemorated in the Prasasti Kudadu (Inscription) issued by Raden Wijaya entitled Kertarajasa Jayawardhana in 1216 (1294). Majapahit Kingdom showed progress from the reign of the Queen Tribhuwana Tunggadewi (1328-1350) and reached its peak during Hayam Wuruk and Gadjah Mada (1350-1389). Majapahit's greatness is at least reflected in Kakawin Negarakertagama, written by Mpu Prapanca (1365), which describes Majapahit's territory beyond the present part of Indonesia. After that time, Majapahit's power began to weaken due to the absence of solid figures and family

\footnotetext{
${ }^{57}$ Sunyoto, Atlas, 227.

58 Widji Saksono, Mengislamkan Tanah Jawa: Telaah atas Metode Dakwah Walisongo (Bandung: Mizan, 1995), 23.
} 
conflicts that struggled for power. ${ }^{59}$ In addition, at the end of its collapse, Majapahit could not cope with new developments, that is the emergence of the influence of Demak Islamic Kingdom on the north coast of Java Island. ${ }^{60}$

When precisely this Hindu-Buddhist kingdom collapsed is not yet known for sure. Majapahit collapsed in 1478 based on traditional sources, but Chinese foreign authorities from the Ming Dynasty still mention the existence of the Majapahit kingdom in 1499. According to the Italian writer Pigafetta in 1522, Majapahit is only mentioned as a city, no longer a kingdom. Unfortunately, the news does not mention the city in question. Another story says that in 1518-1521 Pati Unus as the king of Demak managed to push and subdue Majapahit. ${ }^{61}$ In the Chronicles and other books mentioned Majapahit kingdom collapsed due to the attack of the kings of Demak around 1400. Meanwhile, artifactual and textual data, both inscriptions, works of old Javanese literature, and news from China, provide information on the existence of the Majapahit kingdom until the sixteenth century. ${ }^{62}$

Kiai Fadhol mentions that the Demak attack caused the collapse of the Majapahit Kingdom. After Sunan Ampel died, the guardians were present to make him happy by being led by Raden Paku (Sunan Giri), then buried in the north of his house in Ampel Surabaya. After that, the Javanese walis gathered. They are: Sunan Bonang, Sunan Giri, Sunan Kalijaga, Sunan Drajat, Sunan Gunung Jati, Sunan Muria, Sunan Kudus, Sayyid Muhsin, Sayyid Haji Usman, Raden Patah, Sayyid Usman Haji, Raden Jaka Kondar, and Sayyid Khalifah Shughra b. Sunan Kertayasa. The trustees' association led by Sunan Giri resulted in the decision that Raden Patah was crowned as the leader of Demak Kingdom and made more preparations to fight Majapahit. They negotiated to deter-

\footnotetext{
59 Pusponegoro and Notosusanto, Sejarah Nasional, 450; Kartodirjo, Introduction, 36; Sunyoto, Atlas, 110.

${ }^{60}$ Muhammad Iqbal Birsyada, "Legitimasi Kekuasaan atas Sejarah Keruntuhan Kerajaan Majapahit dalam Wacana Foucault," Walisongo: Jurnal Penelitian Sosial Keagamaan, Vol. 24, No. 2 (2016), 311-332.

${ }^{61}$ R. Cecep Eka Permana, Inspirasi Majapabit: Majapabit dari Dalam Tanah, ed. Daud Aris Tanudirjo (Yogyakarta: PT. Intan Sejati, 2014), 7.

${ }^{62}$ Pusponegoro and Notosusanto, Sejarah Nasional, 450.
} 
mine the warlord until the chosen one was Raden Usman Haji (Sunan Ngudung), the Father of Sunan Kudus. ${ }^{63}$

As for the typology of da'wah developed by the saints in the book explained that to invite a person to the right path should be done in good ways. The book clings to the Qur'ān ud' ila sabil rabbik bi al-bikmah wa al-maw'izat al-ḥasanah, wa jädilhum billati hiya a wise way and good advice (maw izah hasanah), if you have to argue then argue in a dignified way. With modesty in preaching, the community wholeheartedly declared Islam without any coercion, let alone violence. ${ }^{64}$

Picture 3. Typology of Da'wah Wali with Wisdom ${ }^{65}$

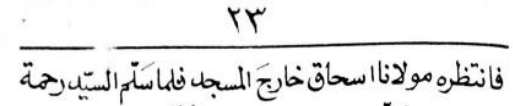

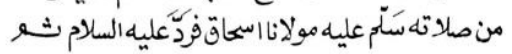

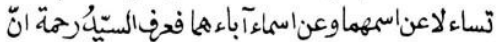

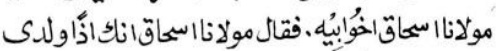

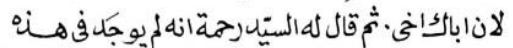

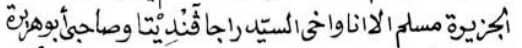

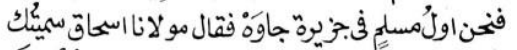

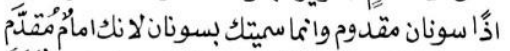

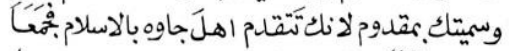

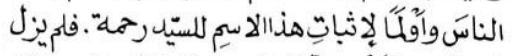

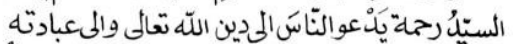

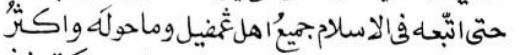

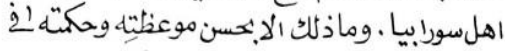

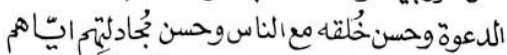

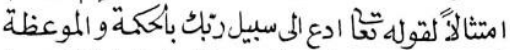

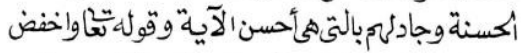

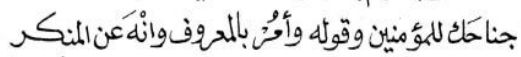

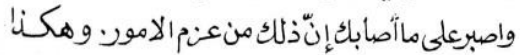

${ }^{63}$ Fadhol, Aḅlà al-Musāmarah, 47.

${ }^{64}$ Ibid., 23.

${ }^{65}$ Documentation of the printed book of Assembly Ta'lif wal Khattath, 2021. 
Once upon a time, towards the end of the war, Amir Haji (Sunan Kudus) as a warlord and Demak's troops moved forward and stopped at Bagendhul. Prabu Brawijaya ordered Gajah Wulung, Pecat Tundha, and Citra Suma to fight Demak's forces. In his journey, Gajah Wulung and Citra Suma died falling from the horse. Now only one of their leaders, the Duke Pecat Tundha, ${ }^{66}$ along with his troops fight against Demak troops. At that time, Pecat Tundha was remembered as the person who killed Usman Haji (Ammir Haji's father) and Amir Hamzah in the previous war. Then there was a fear that Amir Haji would take revenge for his father's death, so that Pecat Tundha fled until he arrived in Terung, his territory. When hearing that Demak's troops arrived in a very urgent position, and that Pecat Tundha and the Majapahit forces had fled, Prabu Brawijaya invited Martaningrum (Sunan Ampel's aunt) to leave the palace to save herself. Still, Martaningrum refused and wanted to remain in the castle to surrender. Then Prabu Brawijaya left the palace until he arrived at Cengkal Sewu village. While in the palace, there is only Martaningrum with 40 servants. Martaningrum told them to prepare to wear Muslim dress to recite the creed. ${ }^{67}$

Majapahit was succesfully conquered. Amir Haji ordered to destroy Majapahit palace and its buildings and take the treasures to Demak as spoils of war (ghanimah). Queen Martaningrum, the wife of Prabu Brawijaya and the aunt of Sunan Ampel, was carried on a prepared vehicle. She was positioned in a vehicle in front of Demak's troops, followed by servants and other soldiers in the trip to Demak, and was greeted by Raden Patah with joy. Under the leadership of Raden Patah, Demak Kingdom prospered. He regulates the affairs of the Muslims in a just and good manner and calls humanity to the religion of Allah with praiseworthy morals. Raden Patah, based in Demak Kingdom, continued to spread

\footnotetext{
${ }^{66}$ Ibid., 80.

${ }^{67}$ Ibid., 81-83. According to other sources, the collapse of Majapahit was caused by both inside and outside factors, such as civil war, weak economic monopoly on the port, and attacks from Demak. See Mas'ud Rofiqi, "Peran Demak terhadap Runtuhnya Majapahit (1478-1527 M)" (BA. Thesis--UIN Sunan Kalijaga Yogyakarta, 2008), 64-67.
} 
Islam with members of the wali council to be widespread to Nusantara. ${ }^{68}$

\section{Conclusion}

From the analysis of the Aḅla al-Musamarah above regarding the role of the Walispeuluh (ten guardians) in the spread of Islam can be concluded: First, the spread of Islam in Nusantara was carried out by the commencement of sayyids of Arab descent through marriage, education, and sufism. Second, the term Walisepulub in the book refers to the names of Sunan Kudus, Sunan Manyuran (Mandalika Jepara), Sunan Kalijaga, Raden Prabu (Sunan Giri II), Sayyid Muhsin (Sunan Wilis), Sunan Drajat, Sunan Muria, Sunan Giri, Raden Patah, and Sunan Bonang. Third, Kiai Fadhol was one of the authors of the historical book that supported the theory that Majapahit collapse was caused by the attack from Demak. Fourth, the character of da'wah developed by the walis in spreading Islam is inclusive, promoting dialogue and tolerance. After paying attention to the historical analysis of Islamization of Nusantara in the book, there are some differences in actors, places, times, and historical plots. Substantive historical studies in the book contain many similarities with the mainstream studies on Islamization in Nusantara.

It is recommended that studies of Islamization in Nusantara should dig a lot of local treasures in the works of Nusantara scholars and in manuscripts that have a high level of historical accuracy. Of course, in this study, there are still some shortcomings, for that we recommend to explore the works of Nusantara scholars because they represent intellectual legacies of high value.

\section{Bibliography}

Amar, Imron Abu. Sejarah Ringkas Kerajaan Islam Demak. Kudus: Menara Kudus, 1996.

Amin, Faizal and Rifki Abror Ananda. "Kedatangan dan Penyebaran Islam di Asia Tenggara: Telaah Teoritik tentang

\footnotetext{
68 Fadhol, Abla al-Musamarah, 84-87. At the end of the book, there is a colophone explaining that the book was printed in Senori, Tuban, Rajab 1, 1415 H, coinciding with December 4, 1994.
} 
Proses Islamisasi Nusantara," Analisis: Jurnal Studi Keislaman, Vol. 18, No. 2, 2018.

Asnawi. Syech Abul Fadol As-Senori at-Tubani. Tuban: Pesantren Langitan, 2004.

Attas (al), Syed Muhammad Naquib. Islam dan Sejarah Kebudayaan Melayu. Kuala Lumpur: Universiti Kebangsaan Malaysia, 1972. Azra, Azyumardi. Islam Nusantara: Jaringan Global dan Lokal. Bandung: Mizan, 2002.

-----. Jaringan Ulama: Timur Tengah dan Kepulauan Nusantara Abad XVII dan XVIII: Melacak Akar-Akar Pembaruan Pemikiran Islam di Indonesia. Jakarta: Mizan, 1994.

Baiti, Rosita and Abdur Razzaq. "Teori dan Proses Islamisasi di Indonesia," Jurnal Wardah, Vol. 28, No. 16, 2014.

Birsyada, Muhammad Iqbal. "Legitimasi Kekuasaan atas Sejarah Keruntuhan Kerajaan Majapahit dalam Wacana Foucault," Walisongo: Jurnal Penelitian Sosial Keagamaan, Vol. 24, No. 2, 2016.

Danandjaja, James. Folklor Indonesia: Ilmu Gosip, Dongeng, dan Lainlain. Jakarta: PT. Pustaka Utama Grafiti, 1997.

De Graaf, H.J. and G. Th. Pigeaud. Chinese Muslims in Java in the 15th and 16th Centuries: The Malay Annals of Semarang and Cerbon. N.p.: Monash Papers on Southeast Asia, 1984.

Djadjadiningrat, Hosein. Islam di Indonesia, ed. Kennet Morgan. Jakarta: PT Pembangunan, 1963.

Documentation of the printed book of Majelis Ta'lif wal Khattath, Tuban, 2021.

Editorial Team. Ensiklopedi Tasawnf, Vol. 1. Bandung: Angkasa, 2008.

Fadhol, Abul. Aḅlā al-Musāmarah fì Hikeàyat al-Awliyà̄' al-'Ashrah. Tuban: Majelis Ta'lif wal Khattath, 1994.

----. Käfiyat al-Tulläb fi Tlm al-Naḅw. Tuban: Majelis Ta'lif wal Khattath, n.d.

----. Sharḥ al-Kawäkib al-Lamäab fi Taḥqiq al-Musammā bi Abl Sunnab wa al-Jama'ab. Tuban: Majelis Ta'lif wal Khattath, n.d.

----. Wali Tanah Jawa (Aḅlā al-Musämarah fì Hikäyat al-Awliyà' al'Ashrah), ed. Nous Team. Kediri: Nous Team Pustaka, 2020. Harun, M. Yahya. Kerajaan Islam Nusantara Abad XVI dan XVII. Yogyakarta: Kurnia Kalam Semesta, 1995. 
Huda, Nor. Sejarah Sosial Intelektual Islam di Indonesia. Jakarta: Raja Grafindo Persada, 2015.

Jannah, Miftakhul and Muhammad Nur Hadi. "Islamisasi Nusantara dan Proses Pembentukan Masyarakat Muslim," Multicultural of Islamic Education, Vol. 2, No. 1, 2018.

Kartodirjo, Sartono. Introduction to The History of New Indonesia: 15001900, From Emporium to Empire. Jakarta: Gramedia, 1987.

Mas'ud, Abdurrahman. "Tārīkh al-Ma'had al-Turāthī wa Thaqāfatu," Studia Islamika, Vol. 7, No. 1, 2000.

Mashar, Aly. "Tasawuf: Sejarah, Madzhab, dan Inti Ajarannya," AlA'raf: Jurnal Pemikiran Islam dan Filsafat, Vol. 12, No. 1, 2015.

Musthofa, Bisri. Sejarah Para Wali (Tärikh al-Awliyā). Yogyakarta: Kalam, 2018.

Ngationo, Ana. "Peranan Raden Patah dalam Mengembangkan Kerajaan Demak pada Tahun 1478-1518," Kalpataru: Jurnal Sejarah dan Pembelajaran Sejarah, Vol. 4, No. 1, 2018.

Nurhisam, Luqman and Mualimul Huda. "Islam Nusantara: A Middle Way?," QIJIS: Qudus International Journal of Islamic Studies, Vol. 4, No. 2, 2016.

Permana, R. Cecep Eka. Inspirasi Majapahit: Majapabit dari Dalam Tanah, ed. Daud Aris Tanudirjo. Yogyakarta: PT. Intan Sejati, 2014.

Pusponegoro, Marwati Djoned and Nugroho Notosusanto. Sejarah Nasional Indonesia, Vol. III. Jakarta: Balai Pustaka, 1990.

Ricklefs, M.C. Sejarah Indonesia Modern. Yogyakarta: Gadjah Mada University Press, 1991.

Rofiqi, Mas'ud. "Peran Demak terhadap Runtuhnya Majapahit (1478-1527 M).” BA. Thesis--UIN Sunan Kalijaga Yogyakarta, 2008.

Saksono, Widji. Mengislamkan Tanah Jawa: Telaah atas Metode Dakwah Walisongo. Bandung: Mizan, 1995.

Suheman, Yuyus. Sejarah Perintisan Penyebaran Islam di Tatar Sunda. Bandung: Pustaka, n.d.

Sunyoto, Agus. Atlas W ali Songo. Jakarta: Pustaka IIman \& LT NU, 2012.

Syafrizal, Achmad. "Sejarah Islam Nusantara," Islamuna: Jurnal Studi Islam, Vol. 2, No. 2, 2015.

Taftāzānī (al), Abū al-Wafā al-Ghanīmī. Madkhal ilà al-Tașawnuf alIslami. Bandung: Pustaka, 1985. 
Ula, Najihah Kamilatul. "KH Abul Fadhol (1917 M-1989 M): Kiai Kharismatik dari Pondok Pesantren Darul Ulum Senori Tuban.” BA. Thesis--UIN Sunan Ampel Surabaya, 2020.

Ulum, Amirul. 3 Ulama Kharismatik Nusantara. Yogyakarta: Global Press, 2016.

Wasid. "Nalar Moderatisme Islam dalam Kitab Sharah al-Kawakib al-Lama'ah by Kiai Abul Fadhal Senori Tuban," 2nd Proceedings Annual Conference for Muslim Scholars, No. 1, April 2018.

Zubair, Maimoen. Fuyūdhat al-Rabbānìah. Rembang: Maktabah alAnwar, n.d.

Zubair. Taräjim Mashäyikh al-Ma'ähid al-Diniyah bi Sarang al-Qudamä'. Rembang: Maktabah al-Anwar, n.d. 